with monochromatic light has very great advantages (as compared with the use of filters) for photochemical experiments in the ultra-violet, especially in the ease and certainty with which an absorbing group can be eliminated from a complex organic molecule by irradiation with light of related frequency. The value of the spectroscopic diagnosis of the structure of the absorbing centres in complex organic compounds will also be rendered much more complete and certain when it is possible to carry out the examination at the temperature of liquid hydrogen, preparations for which are already in progress.

The experiments described above were only possible as a result of the generous co-operation of our biological colleagues in Cambridge and of the Medical Research Council. In particular, we wish to acknowledge our indebtedness to Sir Frederick Gowland Hopkins, Prof. J. B. S. Haldane, Mr. N. W. Pirie, and Dr. B. Woolf of the Sir John Dunn Laboratory of Biochemistry, to Dr. L. J. Harris, Dr. T. Moore, and Mr. T. W. Birch of the Nutrition Laboratory, and to Dr. Bourdillon and his collaborators at Mount Vernon.

F. P. BOwDEN.

C. P. SNow.

Laboratory of Physical Chemistry, Cambridge.

NATURE, April 16, p. 576.

Properties and Structures of Grystalline Vitamins

THE absorption spectra of crystals of ergosterol and calciferol are the same as those of their solutions but for a slight alteration of wave-lengths. The changes produced in solution by irradiation in monochromatic ultra-violet light can also be produced in crystals. They can be observed by the progressive alteration from anisotropic to isotropic material in a polarising microscope. Ergosterol is transformed presumably to calciferol in light of $2967 \mathrm{~A}$., but scarcely at all in 3650,3130 , and $2537 \mathrm{~A}$. Calciferol, on the other hand, is stable at 3650 and $2537 \mathrm{~A}$., but destroyed in $3130 \mathrm{~A}$. This differs from the behaviour of solutions partly on account of the greater absorption and the formation of protecting layers on the surface of the crystals.

$\mathrm{X}$-ray analysis of crystalline vitamins reveals only the general size and shspe of the molecule and is not sensitive to activation. Further work on pyrocalciferol, suprasterol, and also on cholesterol, cholic acid, and pregnandiol, has shown the essential correctness of my previous suggestions on sterol structure. ${ }^{1}$ It is clear that the usually accepted sterol structure must be considerably modified. The crystals of vitamin $B_{1}$ show a large, flat cell, and that and their strong negative birefringence point to ring molecules. The same is true of hexuronic acid. The crystals of $\beta$-carotene and the related $\alpha$-crocetin do not show the long spacings expected from the constitution of these bodies, but further work is necessary to elucidate their structure.

Mineralogical Laboratory, Cambridge.

J. D. Bernat.

1 NATURe, Feb. 20, 1932.

\section{The Oldoway Human Skeleton}

IN Nature of Feb. 27, p. 312, Messrs. Forster Cooper and Watson set out the reasons by which they are "forced to the conclusion that the Oldoway man reached the position in which he was found by an artificial and probably a relatively recent burial". Among the reasons which they adduce for this conclusion is the fact that the "skeleton, which is of modern type, with filed teeth, was found completely articulated down even to the phalanges, and in a position of extraordinary contraction ". As field palæontologists, they regard the possibility of a skeleton getting into the deposits in such a state by natural means as so unlikely, that they find it hard to believe that the skeleton was contemporary with the deposits in which it lay.

In our letter in NATURE of Oct. 24, 1931, p. 724, we stated our conclusion: "There is no possible doubt that the human skeleton . . . came from Bed No. 2 and not from ... Bed No. 4", and we also stated that "Beds Nos. 3 and 4 . . . overlie Bed No. 2 conformably ", but we made no statement that the skeleton was deposited in Bed No. 2 without artificial aid.

Personally, I am quite in agreement with Messrs. Forster Cooper and Watson that a complete articulated human skeleton in the contracted position is not likely to become buried in a lake deposit by natural agencies, but I have never claimed that that happened with the Oldoway skeleton, although I am aware that Prof. Reck did formerly make such a claim.

I am, however, quite satisfied, after examining all the evidence, that Bed No. 3 at Oldoway, with its 50 per cent extinct fauna, was laid down after the skeleton became embedded in Bed No. 2, and that the skeleton was certainly not a subsequent burial into the deposits. My own personal belief is that contemporary man, living on the edge of the then existing Oldoway lake, buried the skeleton into the muddy, clayey edge of the lake whilst Bed No. 2 was in process of being deposited, for Bed No. 2 is essentially a shallow water deposit at the place where the skeleton was found. Bed No. 3, which is of a brilliant red colour and of quite a different texture, was then deposited above it.

It would take too much space to set out here all the geological and other evidence which shows that the skeleton was already in Bed No. 2 before Bed No. 3 was laid down, but I may perhaps summarise some of the chief reasons, as follows :

Bed No. 2, which contained the skeleton, is of a yellow colour, and the skeleton lay in its topmost levels. Immediately over it lies Bed No. 3, which is red in colour and of a quite different texture.

The position of the skeleton was such that unless it had been buried into the deposits within the last few years (at most fifty) any supposed grave-digging into Bed No. 2 must also have affected Bed No. 3, and it thus follows that, unless the skeleton was a burial of the past very few years, the refilling of the grave must have resulted in an admixture of red and yellow material around the body.

I was lucky enough personally to examine the skeleton at Munich while it was still intact in its original matrix, and could detect no trace whatever of such admixture, or of disturbance.

The bones of the skeleton, while not so heavily mineralised as those from Bed No. 3 or even Bed No. 1, are, so far as I know, every bit as mineralised as most of the bones from Bed No. 2 itself. This less complete mineralisation is presumably due to the varying nature of the deposits.

I have personally examined the so-called 'filing' of the teeth of the Oldoway man on the original specimen at Munich, and this 'filing' has no resemblance to any filing done by native tribes to-day, and it is, to my mind, exceedingly doubtful if it can be called filing at all.

I hope that Messrs. Watson and Forster Cooper will have been satisfied by this statement of mine, incomplete though it is, but $\mathrm{I}$ should like to give them still further evidence in support of the genuineness of the antiquity of Homo sapiens in East Africa.

During the past six weeks, I have been carrying out investigations on the north-east shore of Victoria Nyanza, at the well-known fossil beds in the region of Kendu and Homo on the south side of the Kavirondo Gulf. 